\title{
EHMTI-0248. Evaluation of headache prevalence and characteristics in orphans aged 12-17
}

\author{
A Ates Senturk*, B Alpaslan, U Uygunoglu, D Uluduz, S Saip, A Siva \\ From 4th European Headache and Migraine Trust International Congress: EHMTIC 2014 \\ Copenhagen, Denmark. 18-21 September 2014
}

\section{Introduction}

The epidemiological studies show that presence of divorced parents or loss of a parent is a risk factor for headache during childhood.

\section{Aims}

We aimed to investigate the frequency, clinical features, trigger factors, comorbidities, effects on daily life and accompanying emotional and behavioral problems of the migraine and tension-type headache(TTH) in the orphan children.

\section{Methods}

We performed our study in a school where the orphan children study.415 students of 12-17 age group are counted in the study.PedMIDAS scale of 5 questions and strength and difficulties questionnaire of 25 questions are asked to fill. The results are compared by dividing the children into 2 groups of 12-14 and 15-17 age groups.

\section{Results}

In the 12-14 age group, the frequency of primary headache is found as $59,8 \%$ with the frequency of migraine is $24,4 \%$ and the frequency of TTH is $35,4 \%$. In the 15 17 age group the frequency of headache is $59,7 \%$ and $23,6 \%$ of them were composed of migraine where as the $36,1 \%$ of them fulfil the criteria of TTH.

\section{Conclusions}

Stressful life events during childhood such as parent loss is found to be relevant with becoming chronic and higher frequency of headache.

No conflict of interest.

Neurology Department, Istanbul University Cerrahpasa Medical Faculty, Istanbul, Turkey

\section{SpringerOpen $^{\odot}$}

Published: 18 September 2014

doi:10.1186/1129-2377-15-S1-B34

Cite this article as: Senturk et al:: EHMTI-0248. Evaluation of headache prevalence and characteristics in orphans aged 12-17. The Journal of Headache and Pain 2014 15(Suppl 1):B34.

\section{Submit your manuscript to a SpringerOpen ${ }^{\circ}$} journal and benefit from:

- Convenient online submission

- Rigorous peer review

- Immediate publication on acceptance

- Open access: articles freely available online

- High visibility within the field

- Retaining the copyright to your article 